Psihologijske teme, 27 (2018), 3, 561-583

Izvorni znanstveni rad - UDK - 159.923.072

159.942 .072

doi:https://doi.org/10.31820/pt.27.3.11

\title{
Efekti crta ličnosti tamne trijade i emocionalne empatije na moralnu prosudbu
}

\author{
Ana Rožić, Domagoj Švegar i Igor Kardum \\ Sveučilište u Rijeci, Filozofski fakultet, Odsjek za psihologiju, Hrvatska
}

\begin{abstract}
Sažetak
Klasične moralne dileme žrtvovanja, u kojima je potrebno žrtvovati život jedne osobe kako bi spasili nekoliko drugih života, često su definirane konfliktom između racionalnog odgovora maksimizacije ukupne dobrobiti (utilitaristička moralna prosudba) i emocionalne averzije na povredu (deontološka moralna prosudba). Novija su istraživanja moralnog prosuđivanja pokazala da su socijalno averzivni stilovi ličnosti povezani sa sklonosti utilitarističkom odgovaranju na moralne dileme. Cilj je ovoga istraživanja bio ispitati povezanosti crta ličnosti tamne trijade i odgovora na moralne dileme, kao i medijacijski efekt emocionalne empatije na tu povezanost. U istraživanju je sudjelovalo 210 ispitanika u dobi od 18 do 68 godina, od toga 147 žena i 63 muškaraca. Dobiveni su rezultati pokazali da su viša psihopatija i viši makijavelizam povezani s većom sklonosti utilitarističkoj moralnoj prosudbi. Nije pronađena povezanost narcizma i moralne prosudbe. Žene iskazuju višu emocionalnu empatiju, a muškarci višu psihopatiju i veću sklonost utilitarističkoj moralnoj prosudbi. Viša je emocionalna empatija povezana s nižim narcizmom, nižim makijavelizmom i nižom psihopatijom te manjom sklonosti utilitarističkoj moralnoj prosudbi. Niska emocionalna empatija je značajan medijator povezanosti makijavelizma i psihopatije sa sklonosti utilitarističkoj moralnoj prosudbi. Raspravljeni su efekti crta tamne trijade i emocionalne empatije na moralnu prosudbu.
\end{abstract}

Ključne riječi: crte ličnosti tamne trijade, emocionalna empatija, moralna prosudba, moralne dileme žrtvovanja

\section{Uvod}

Racionalni model moralnog prosuđivanja, prema kojem su moralno znanje i moralne prosudbe primarno uzrokovane procesima rasuđivanja i refleksije (Kohlberg, 1969), dugo je bio dominantan u psihologiji morala. U suprotnosti s takvim tradicionalnim racionalnim modelom Haidt (2001) izravan uzrok moralnim prosudbama vidi $u$ moralnim intuicijama $\mathrm{i}$ emocijama te naglašava socijalne $\mathrm{i}$ kulturalne utjecaje na moralno prosuđivanje. Moralne se intuicije javljaju brzo,

Domagoj Švegar, Odsjek za psihologiju, Filozofski fakultet, Sveučilište u Rijeci, Sveučilišna avenija 4, 51000 Rijeka, Hrvatska. E-pošta: dsvegar@uniri.hr 
automatski i bez napora, kao evaluativan osjećaj je li nešto dobro ili loše, pri čemu je samo rezultat, ali ne i proces, dostupan svijesti. S druge strane, rasuđivanje se javlja sporije, zahtijeva kognitivni napor i barem nekoliko koraka koji su dostupni svijesti (Haidt, 2001).

Prema modelu dualnog procesiranja (Greene, Nystrom, Engell, Darley i Cohen, 2004), koji nastoji pomiriti dva različita viđenja o procesima u podlozi moralnosti, i afektivni i kognitivni procesi pridonose moralnim prosudbama. Unutar tog modela razlikuju se dva kvalitativno različita načina moralnoga mišljenja koja ovise o dva nezavisna sustava. Jedan je sustav primarno vođen intuitivnim emocionalnim odgovorima, dok je drugi vođen kontroliranim kognitivnim procesima. Sukladno tome, odgovori na moralne dileme vođeni su dvama moralnim principima, deontološkim i utilitarističkim. Deontologija je znanost o dužnostima i obavezama, a deontološka etička perspektiva tretira moralna pravila kao apsolutna, što znači da su ih ljudi dužni slijediti. Deontološko rezoniranje reflektira brigu za prava i dužnosti i usredotočeno je na sredstva. Prema tome, iz deontološke je perspektive povreda druge osobe moralno neispravna čak i kada je u službi najboljeg ishoda, zato jer se ljude tretira kao sredstva za postizanje cilja, a ne kao cilj sam po sebi. Utilitarističko rezoniranje je usredotočeno na ishode, najvažnije je postići najbolji ishod, pri čemu sredstva nisu relevantna. Akcija koja proizvodi najbolji ukupni ishod moralno je prihvatljiva, makar rezultirala povredom ili štetom. Dakle, prema utilitarizmu moralnost akcije determinirana je njezinim posljedicama, odnosno važno je da je dobit veća od gubitka (Conway i Gawronski, 2013).

U empirijskim istraživanjima moralne kognicije često se koriste moralne dileme - kratke priče o situacijama koje uključuju različite moralne konflikte, najčešće između osobnih interesa i prihvaćenih moralnih vrijednosti, različitih dužnosti, skupa nerazmjernih vrijednosti ili jedinstvenoga moralnog principa (Christensen i Gomila, 2012). Korištenje je moralnih dilema žrtvovanja, u kojima je potrebno žrtvovati život jedne osobe kako bi spasili nekoliko života, pokazalo da na moralne dileme utječu i emocije i razum. Pretpostavlja se da se deontološki odgovori (npr. Nije moralno prihvatljivo ubiti jednog čovjeka kako bi spasili petero ljudi.) oslanjaju na intuitivnoemocionalno procesiranje, tj. na emocionalne reakcije na radnju koja nanosi štetu drugima, dok utilitaristički odgovori (npr. Moralno je prihvatljivo ubiti jednog čovjeka kako bi spasili petero ljudi.) proizlaze iz hladnijeg i promišljenijeg procesiranja, $\mathrm{tj}$. kognitivne analize dobitaka i troškova vezanih uz posljedice radnje (Greene i sur., 2004).

Haidt i Graham (2007) smatraju da moralnost možemo razumjeti u terminima pet psiholoških sustava koji su u podlozi pet moralnih temelja. To su: šteta-briga (suosjećanje i briga o nasilju nad drugima i patnji drugih), pravednost-reciprocitet (norme recipročnih odnosa, jednakost, pravo i pravda), vjernost vlastitoj grupi (moralne obveze povezane s pripadanjem grupi, kao što su vjernost, izdaja, očekivanja povlaštenog tretmana za članove vlastite grupe), autoritet-poštovanje (moralne obveze povezane s hijerarhijskim odnosima, kao što su poslušnost, dužnost, poštivanje nadređenih, zaštita podređenih) te čistoća-svetost (moralni ideal življenja 
uzvišenim, plemenitim i manje tjelesnim načinom, na temelju intuicija o božanskom, svetosti tijela, uma i duše te osjećajima moralnog gađenja). Jedan od Haidtovih i Grahamovih (2007) pet moralnih temelja, šteta-briga, od kritičnog je interesa u kontekstu moralnih dilema žrtvovanja. Ta se komponenta odnosi na našu evolucijski stečenu sposobnost empatije i zaštite fizičkog integriteta drugih osoba, a uključuje suosjećanje, sposobnost osjećanja tuđe boli i patnje.

Prema Greenu i sur. (2004) kad su ljudi suočeni s moralnom dilemom u kojoj jedna osoba mora biti ubijena kako bi se spasilo više drugih osoba, ljudi neposredno i nehotično doživljavaju negativnu emocionalnu reakciju uzrokovanu povredom druge osobe. Ako je ta emocionalna reakcija dovoljno snažna ili ako ljudi nemaju dovoljno vremena, motivacije ili resursa za utilitarističko razmatranje, emocionalna će reakcija dominirati u procesu donošenja odluka te dovesti do deontološke moralne prosudbe: ubijanje je moralno neprihvatljivo. Kod uvjeta koji dopuštaju više razmišljanja, vremena, motivacije i resursa, ljudi se mogu uključiti u procese razmatranja troškova i prednosti povrede druge osobe. Ti kognitivni procesi mogu dominirati procesom donošenja odluka i rezultirati utilitarističkom prosudbom (Conway i Gawronski, 2013). Sukladno tome, utilitaristički je odgovor na moralne dileme konzistentno pronađen kao moralno prihvatljiviji za osobe $\mathrm{s}$ višim kapacitetom radnog pamćenja (Moore, Clark i Kane, 2008). Također, eksperimentalno inducirana promišljenost prije moralnih dilema dovodi do više utilitarističkih odgovora (Paxton, Ungar i Greene, 2011), dok kognitivno opterećenje s njima selektivno interferira (Greene, Morelli, Lowenberg, Nystrom i Cohen, 2008). Budući da utilitarizam proizlazi iz kontroliranih procesa, to je neke znanstvenike navelo na zaključak da je to optimalna moralna prosudba i da osobe koje čine neutilitarne, odnosno deontološke odgovore na moralne dileme čine pogrešku (Greene i sur., 2009).

\section{Osobine ličnosti i moralno prosuđivanje}

Empatija i moralnost konceptualno su povezani. Smatra se da empatija ima ključnu ulogu u moralnom ponašanju, odnosno da funkcionira kao emocionalni moralni barometar koji pruža neposrednu povratnu informaciju za ponašanje (Tangney, Stuewig i Mashek, 2007), a preko emocija kao što su briga i krivnja ima motivacijsku moć za odabir moralno ispravnog ponašanja (Moll i de Oliveira-Souza, 2007). U istraživanjima Choe i Min (2011) te Patil i Silani (2014) ustanovljena je značajna negativna povezanost empatije i utilitarističke moralne prosudbe. Gleichgerrcht i Young (2013) istraživali su koji je specifični aspekt emocionalnog odgovaranja relevantan za moralne prosudbe te je li on selektivno smanjen kod onih ljudi koji odgovaraju utilitaristički ili povećan kod onih koji odgovaraju deontološki. Rezultati su pokazali da niska empatična briga (npr. osjećaji topline i suosjećanja za nekoga u nevolji) predviđa sklonost utilitarističkom odgovoru na moralne dileme. Unutar složene domene empatije utilitaristička je prosudba konzistentno predviđena samo od strane empatičke brige, emocionalne komponente empatičkog odgovora. 
Sukladno tome, crte ličnosti povezane sa smanjenom empatijom trebale bi pokazati veću sklonost utilitarističkom odgovoru na moralne dileme. Niska je empatija karakteristična za tamnu trijadu (Jones i Figueredo, 2013; Wai i Tiliopoulos, 2012), koju čine tri socijalno averzivne supkliničke crte ličnosti: makijavelizam, psihopatija i narcizam (Paulhus i Williams, 2002). Osobe koje postižu visoke rezultate na skali makijavelizma (Barlow, Qualter i Stylianou, 2010), narcizma (Watson i Morris, 1991) i psihopatije (Mahmut, Homewood i Stevenson, 2008) konzistentno pokazuju nisku empatiju.

Konstrukt supkliničkog narcizma uključuje facete grandioznost, privilegiranost, dominantnost i superiornost (Raskin i Hall, 1979). Narcistički koncept selfa obilježen je pozitivnošću, egocentrizmom i osjećajem posebnosti, a takav koncept osoba strateški regulira vanjskim prikazom vlastite važnosti, fantazijama o slavi i moći te negativnim emocionalnim reakcijama na percipiranu prijetnju selfu. Interpersonalne su veze narcističkih pojedinaca karakterizirane iskorištavanjem drugih za zadovoljavanje vlastite potrebe za divljenjem i potvrdom, ravnodušnošću prema tuđim potrebama i osjećajem privilegiranosti (Campbell, Reeder, Sedikides i Elliot, 2000). Psihopatija je karakterizirana visokom impulzivnosti i traženjem uzbuđenja te niskom empatijom i anksioznosti (Hare, 1985). Temeljne su karakteristike psihopatije: egocentričnost, nesposobnost formiranja bliskih odnosa, niska anksioznost, nedostatak osjećaja krivnje, neosjetljivost, nepoštenje, površni šarm i eksternalizacija krivnje (Hare, 1991). Konstrukt makijavelizma nastao je iz sustava vjerovanja i osobne filozofije političkog savjetnika Nicole Machiavellija, koja naglašava cinično, manipulativno i nemoralno ponašanje (Christie i Geis, 1970). Prema Machiavelliju vladar održava moć koristeći obmanu i iskorištavajući svoje podanike, po načelu "cilj opravdava sredstvo" (Fehr, Samsom i Paulhus, 1992). Makijavelisti najbolje uspijevaju u kontekstima interakcije licem u lice, kada je moguće improvizirati i kada ima puno emocionalnih distrakcija. Njihovo ponašanje nije agresivno, već se koriste laganjem, varanjem i prijevarom. Imaju ciničan pogled na svijet, pragmatičnu etiku i koriste se obmanom; mogu identificirati i iskoristiti slabosti kod drugih ljudi, skrivajući vlastite (Christie i Geis, 1970).

Nedostatak empatije, što je zajednička karakteristika svih triju crta tamne trijade, omogućuje manipulaciju drugima (Jones i Paulhus, 2011). Sistematskim pregledom literature Furnham, Richards, Rangel i Jones (2014) pokazuju da su skoro sve interkorelacije među crtama tamne trijade pozitivne i značajne, da su najveće korelacije između psihopatije i makijavelizma, a najmanje između narcizma i makijavelizma. Kontinuirana je pozitivna korelacija među crtama ličnosti tamne trijade moguće posljedica jedne zajedničke komponente, a Jones i Figueredo (2013) ustanovili su da je manipulativnost-neosjetljivost, odnosno niska empatija karakteristika koja čini zajedničku tamnu srž tamne trijade. Kada se ta komponenta izdvoji, crte tamne trijade više nisu povezane.

Wai i Tiliopoulos (2012) ispitivali su deficite kognitivne i afektivne empatije kod tamne trijade. Pojedinci visoko na bilo kojoj skali tamne trijade imali su nižu afektivnu, ali ne i kognitivnu empatiju, dok su pojedinci s višim narcizmom čak 
pokazali višu kognitivnu empatiju. Takav empatički profil dopušta im da sposobnosti čitanja i procjene tuđeg emocionalnog stanja koriste za stvaranje strategija koje će im pomoći u ostvarenju ciljeva, dok im nedostatak afektivne empatije može omogućiti zanemarivanje potencijalne štete koju će proizvesti drugima u tom procesu. Pozitivna povezanost narcizma i kognitivne empatije moguće proizlazi iz narcističke potrebe za divljenjem i potkrepljenjem slike o sebi. Delič, Novak, Kovačič i Avsec (2011) ustanovili su pozitivnu povezanost između narcizma, emocionalne i socijalne inteligencije. To je i logično, jer da bi zadovoljile svoje potrebe za potvrdom i divljenjem, osobe s izraženim narcizmom moraju razviti dobre interpersonalne vještine $i$ emocionalnu inteligenciju kako bi mogli bolje razumijeti kako ih drugi vide, ali ne nužno i empatičku brigu za druge. Kod psihopatije je nesposobnost empatije upotpunjena nedostatkom krivnje, žaljenja i pokajanja (Williams i Paulhus, 2004), dok je makijavelizam pozitivno povezan sa sklonosti sramu, ali i negativno sa sklonosti krivnji (Wastell i Booth, 2003). Takvi deficiti, karakteristični za tamnu trijadu, rezultiraju u nesposobnosti emocionalnog povezivanja s drugima te korištenju drugih kao objekata koji zadovoljavaju osobne ciljeve.

Međutim, iz evolucijske perspektive crte tamne trijade nisu nepoželjne i patološke osobine, već zapravo mogu biti pseudopatologije. Društvo na njih ne gleda blagonaklono jer predstavljaju prijetnju zajedničkom dobru, no na individualnoj razini mogu imati prednosti (Jonason, Duineveld i Middleton, 2015). Moguće je da je niska empatija, koja je u podlozi tamne trijade, neophodan dio složenih psiholoških adaptacija potrebnih za uspjeh u korištenju socijalnih ili seksualnih strategija koje se temelje na iskorištavanju. Istraživanja pokazuju da su crte ličnosti tamne trijade izraženije kod muškaraca nego kod žena (Jonason i Kroll, 2015), a te su razlike posredovane empatijom, za koju žene imaju veći kapacitet nego muškarci (Jonason, Lyons, Bethell i Ross, 2013). Ako muškarci imaju više koristi od antisocijalnog ponašanja, moguće je da im je prirodna selekcija pridružila više razine psihopatije i niže razine empatije u usporedbi sa ženama (Jonason i Kroll, 2015). U skladu s time Jonason i Krause (2013) su otkrili složene korelacijske obrasce između crta ličnosti tamne trijade i dva oblika "emocionalnih nedostataka", niske empatije i aleksitimije, općenito i za svaki spol posebno. Psihopatija je bila povezana s niskom ukupnom empatijom, teškoćama u opisivanju emocija i eksternalno orijentiranim mišljenjem, narcizam s niskom afektivnom empatijom i teškoćama identificiranja osjećaja, a makijavelizam s eksternalno orijentiranim mišljenjem. Tamna trijada pokazala se kao medijator spolnih razlika u empatiji i eksternalno orijentiranom mišljenju. Jonason i Kroll (2015) su još ustanovili da je kod žena viša empatija povezana s narcizmom te da su deficiti empatije kod žena više povezani s antisocijalnim osobinama nego kod muškaraca. Osim toga, kod žena je niska empatijska briga povezana s psihopatijom i makijavelizmom, a kod muškaraca samo s psihopatijom.

Povezanost crta tamne trijade s različitim sustavima moralnih i socijalnih vrijednosti istraživali su Jonason, Strosser, Kroll, Duineveld i Baruffi (2015). Pokazalo se da je psihopatija povezana sa smanjenom brigom za sve moralne temelje 
(šteta, pravednost, vjernost vlastitoj grupi, autoritet, čistoća). Makijavelizam je povezan s moralnom fleksibilnosti, a narcizam sa socijalno poželjnim oblikom moralnosti. Makijavelizam i psihopatija povezani su s manjim vrednovanjem kolektivnih interesa, a narcizam s vrednovanjem individualnih interesa kroz jačanje selfa. Psihopatija je primarno povezana sa smanjenim razmatranjem moralnih temelja štete/brige i pravednosti kod moralnog prosuđivanja. Empatička se briga pokazala kao medijator veze između psihopatije i moralnih temelja štete/brige i pravednosti, odnosno njezin bi nedostatak mogao biti odgovoran za razlike u moralnim prosudbama koje uzimaju u obzir hoće li drugi ljudi biti povrijeđeni i hoće li biti tretirani nepravedno. Moguće je da psihopatima dobrobit drugih ljudi nije istaknuta briga što ih onda i ne sprječava da iskazuju nemoralno ponašanje koje drugima šteti ili ih iskorištava (Glenn, Iver, Graham, Koleva i Haidt, 2009).

Novija su istraživanja moralnog prosuđivanja pokazala da su socijalno averzivni stilovi ličnosti skloni utilitarističkom odgovaranju u moralnim dilemama (Bartels i Pizzaro, 2011; Djeriouat i Tremoliere, 2014). Istraživanje Bartelsa i Pizzara (2011) dovodi u pitanje mišljenje da je utilitarizam odgovarajući okvir odnosno normativni standard prema kojem treba evaluirati moralne prosudbe, odnosno preispituju kriterij prema kojem pojedinci koji odabiru deontološke odgovore na moralnim dilemama zapravo čine moralne pogreške. Ispitanici koji su skloniji utilitarističkom odgovoru na moralne dileme imaju više rezultate na mjerama psihopatije, makijavelizma i beznačajnosti života. Ovakvi rezultati dovode u pitanje kako se evaluiraju moralne prosudbe s obzirom na to da takvi pristupi dovode do kontraintuitivnog zaključka da oni pojedinci koji su najmanje skloni moralnim greškama posjeduju skup karakteristika koje bi većina ljudi smatrala prototipično nemoralnima. Njihovo istraživanje kritizira široko prihvaćenu uporabu moralnih dilema žrtvovanja u istraživanju moralnog prosuđivanja, koje ne uspijevaju razlikovati ljude koji su motivirani donositi utilitarističke moralne izbore zbog pozadinskih emocionalnih deficita od onih koji ih čine zbog iskrene brige za tuđu dobrobit i vjeruju da je utilitarizam optimalan način postizanja ciljeva moralnosti. Djeriouat i Tremoliere (2014) su ispitivali efekte crta ličnosti tamne trijade i međusobno djelovanje prosocijalne orijentacije (HEXACO faktor iskrenost/ skromnost) i moralne grupe vrijednosti povezanih s empatijom (šteta/briga) na moralne prosudbe vezane uz moralne dileme žrtvovanja. Rezultati su pokazali da su crte ličnosti tamne trijade pozitivno povezane s utilitarizmom i da su medijatori te povezanosti iskrenost/skromnost iz HEXACO modela ličnosti i moralne vrijednosti šteta/briga. Šteta/briga i iskrenost/skromnost negativni su medijatori te veze kada su nezavisni prediktori makijavelizam i psihopatija, ali ne i kada je nezavisni prediktor narcizam. Od crta ličnosti tamne trijade psihopatija je jedini nezavisni prediktor štete/brige i utilitarizma, pokazujući da je sklonost utilitarizmu iskazana kao niska briga za princip štete i prosocijalna ponašanja, što sugerira da utilitarizam može proizići iz inhibicije moralne deontologije, a ne zagovaranja veće ukupne dobrobiti. Istraživanje Gleichgerrcht i Young (2013) prema kojem niska empatična briga predviđa sklonost utilitarističkom odgovoru na moralne dileme $\mathrm{i}$ istraživanje Patil i 
Silani (2014) u kojem aleksitimija, s dokazanim deficitima u empatiji, pokazuje značajnu pozitivnu povezanost $\mathrm{s}$ utilitarističkom moralnom prosudbom, također sugerira da postoji alternativni put do utilitarističke moralne prosudbe, preko niske empatije i zanemarivanja moralne deontologije. Ovakvi su rezultati u skladu s mišljenjem Bartelsa i Pizzara (2011) da odabir utilitarističke opcije nije uvijek pitanje postizanja većeg dobra, nego može odražavati indiferentnost prema važnosti osnovnih moralnih dužnosti (kao što je princip nenanošenja štete). Moguće je da je utilitaristički odgovor na moralne dileme kod osoba s izraženim crtama ličnosti tamne trijade više povezan s manjkavim emocionalnim funkcioniranjem, koje dovodi do sklonosti zanemarivanja moralne deontologije kao irelevantne, nego $\mathrm{s}$ odobravanjem utilitarizma kao primarnog principa.

\section{Cilj istraživanja}

Cilj je ovoga istraživanja bio ispitati povezanosti crta ličnosti tamne trijade $\mathrm{i}$ odgovora na moralne dileme, kao i medijacijski efekt emocionalne empatije na tu povezanost. Istraživanja koja su se bavila ovom tematikom su malobrojna, a istraživanje slično ovome dosad nije provedeno na hrvatskom uzorku.

Očekuje se da će crte ličnosti tamne trijade biti pozitivno povezane sa sklonosti utilitarističkom odgovoru na moralne dileme, a negativno povezane s emocionalnom empatijom. Također se očekuje da će niska emocionalna empatija biti statistički značajan medijator povezanosti sklonosti utilitarističkom odgovoru i crta ličnosti tamne trijade, među kojima se očekuje da će jedino psihopatija biti značajan nezavisan pozitivan prediktor sklonosti utilitarističkom odgovoru na moralne dileme.

\section{Metoda}

\section{Ispitanici}

U istraživanju je sudjelovalo 210 ispitanika, od čega 147 žena (70\%) i 63 muškaraca (30\%). Prosječna dob ispitanika je 28.27 godina $(S D=9.21$, raspon:1868). Uzorak ispitanika je prigodan, čine ga osobe koje su se dobrovoljno odazvale na poziv za sudjelovanje $u$ istraživanju, preko društvenih mreža i elektroničkom poštom te ispunile internetski upitnik Google Docs. Pregled obrazovne strukture pokazuje da je većina ispitanika, njih 109 (51.9\%), završila višu školu ili fakultet, 66 (31.4\%) ispitanika je završilo srednju školu, 34 (16.2\%) ispitanika ima završeno poslijediplomsko obrazovanje, magisterij ili doktorat, a jedan ispitanik $(0.5 \%)$ ima završenu osnovnu školu. 


\section{Mjerni instrumenti}

U istraživanju su ispitanici odgovorili na nekoliko demografskih pitanja (spol, dob, stupanj obrazovanja), ispunili pet upitnika (Skala emocionalne empatije, Marlowe-Crowneova skala socijalne poželjnosti, Upitnik narcističke ličnosti, Test makijavelizma, Skala samoprocjene psihopatije) te odgovorili na četiri moralne dileme korištene kao zadatak moralnog prosuđivanja.

Skala emocionalne empatije (Raboteg-Šarić, 2002) mjeri opću afektivnu empatiju, a sastoji se od 19 tvrdnji koje opisuju emocionalne doživljaje koji su u skladu s emocionalnim stanjem drugih te osjećaje simpatije prema onima koji su u nevolji (npr. Uznemiruje me kad vidim da drugi plaču.; Ćesto me neke situacije ili ljudi "dirnu u srce".). Ispitanici trebaju na skali procjene od pet stupnjeva odgovoriti u kojoj se mjeri sadržaj tvrdnje odnosi na njih (0 - uopće se ne odnosi na mene, 4 u potpunosti se odnosi na mene). Skalom se mjeri jednodimenzionalni konstrukt, stoga je ukupni rezultat linearna kombinacija skalnih vrijednosti. Raspon je rezultata od 0 do 76 bodova, a viši rezultat na skali znači veću tendenciju doživljavanja emocionalne empatije.

Marlowe-Crowneova skala socijalne poželjnosti (Crowne i Marlowe, 1964) mjera je za procjenu utjecaja socijalne poželjnosti na odgovaranje u upitnicima ličnosti, a kasnija su istraživanja pokazala da mjeri širi konstrukt, koji su autori nazvali potrebom za odobravanjem, odnosno izbjegavanjem neodobravanja. Čestice opisuju poželjna, ali neuobičajena ponašanja (npr. Uvijek priznam kada učinim neku pogrešku.) i nepoželjna, ali uobičajena ponašanja (npr. Događalo mi se da sam bio ljubomoran na uspjehe drugih.). U ovom je istraživanju korištena skraćena verzija skale adaptirana na hrvatski jezik (Bezinović, 1988). Sastoji se od 13 tvrdnji na koje ispitanik, ako je iskren, može odgovoriti na samo jedan način. Ispitanik na tvrdnje odgovara s točno ili netočno, a ukupan je rezultat zbroj socijalno poželjnih odgovora. Raspon je rezultata od 0 do 13 bodova. Visok rezultat na ovoj skali sugerira da osoba ima tendenciju davanja socijalno poželjnih odgovora, ima nerealističnu percepciju sebe ili se namjerno prikazuje u što boljem svjetlu.

Upitnik narcističke ličnosti je hrvatska verzija mjere subkliničkog narcizma Narcissistic Personality Inventory (NPI-40; Raskin i Terry, 1988). Sadrži 40 parova tvrdnji na koje ispitanici odgovaraju tako da odaberu jednu od dvije tvrdnje, A ili B, za koju smatraju da je bliža njihovim vjerovanjima i osjećajima (npr. A: Uglavnom sam kao i drugi ljudi. / B: Ja sam izuzetna osoba.). Ukupan se broj narcističkih tvrdnji koje ispitanik odabere koristi kao indeks narcizma, koji se može kretati od 0 do 40 bodova.

Test makijavelizma je hrvatska verzija mjere makijavelizma Test of Machiavellianism (Mach-IV; Christie i Geis, 1970). Sadrži 20 čestica koje opisuju uobičajeno mišljenje i stavove karakteristične za makijaveliste (npr. Svatko tko ima potpuno povjerenje u druge izaziva nevolju.). Ispitanici trebaju procijeniti stupanj slaganja s tvrdnjama na skali procjene od šest stupnjeva (od +3 slažem se izrazito do 
-3 ne slažem se izrazito). Ukupan se rezultat dobiva zbrajanjem bodova na svim tvrdnjama, u smjeru koji upućuje na veći makijavelizam. Indeks makijavelizma može se kretati od 20 do 120 bodova.

Skala samoprocjene psihopatije je hrvatska verzija mjere subkliničke psihopatije Self-Report Psychopathy Scale (SRP-III; Hare, 1985). Sadrži 31 tvrdnju (npr. Zadovoljstvo mi je varati ljude.) za koje ispitanici trebaju procijeniti stupanj slaganja na skali procjene od 5 stupnjeva (od jako se ne slažem do jako se slažem). Ukupan je rezultat zbroj bodova na svim tvrdnjama, u smjeru koji upućuje na veću psihopatiju. Indeks psihopatije može se kretati od 31 do 155 bodova.

Sva tri upitnika crta ličnosti tamne trijade korištena su kao jednodimenzionalne mjere te su validirani i korišteni na hrvatskim uzorcima u prijašnjim istraživanjima (Kardum, Hudek-Knežević, Schmitt i Grundler, 2015). Povezanost je između crta ličnosti tamne trijade pozitivna: koeficijenti korelacije u ovom istraživanju iznose .38 između psihopatije i narcizma, .30 između psihopatije i makijavelizma i .25 između makijavelizma i narcizma, što je u skladu s ranijim istraživanjima (Furnham i sur., 2014; Kardum i sur., 2015).

Zadatak moralnog prosuđivanja sastoji se od četiri kratke priče, odabrane i prilagođene iz istraživanja Greenea, Sommervillea, Nystroma, Darleya i Cohena (2001), koje slijede istu strukturu i dilemu: ubiti jednu kako bi spasili pet osoba. Odabrane moralne dileme sadrže konflikte u kojem se krše principi nenanošenja štete jer se pretpostavlja da osobe visoko na crtama ličnosti tamne trijade zanemaruju važnost tih principa. U svakoj moralnoj dilemi suprotstavljene su utilitaristička i deontološka opcija. Ispitanici trebaju odgovoriti na skali od 4 stupnjeva (od 1 'ne' do 4 'da') koliko je neka akcija moralno prihvatljiva (utilitaristička opcija) ili nije (deontološka opcija). Primjer dileme: Ti si vođa male grupe vojnika. Na povratku s misije duboko u neprijateljskom teritoriju jedan od tvojih ljudi je stao u neprijateljsku zamku i teško je ozlijeđen. Zamka je povezana s uređajem koji je obavijestio neprijatelja o vašoj prisutnosti. Uskoro će biti na putu prema vama. Ako neprijatelj nađe tvojega ozlijeđenog vojnika, mučit će ga i ubiti. Jedini način da spriječiš mučenje vojnika je da ga sam/a ustrijeliš. Ako ga uzmeš sa sobom, tvoja će cijela grupa, ozlijeđeni vojnik i ostalih pet vojnika, biti uhvaćena. Je li moralno prihvatljivo u ovakvoj situaciji ustrijeliti ozlijeđenog vojnika kako bi spasio/la ostale vojnike? Za svakog je ispitanika izračunat prosječan rezultat odgovora na moralnim dilemama (zbroj rezultata na svim moralnim dilemama/broj moralnih dilema), pri čemu viši rezultat odražava veću sklonost utilitarističkoj moralnoj prosudbi.

\section{Postupak}

Istraživanje je provedeno web-upitnikom, anketom Google Docs. Poziv na sudjelovanje $u$ istraživanju proslijeđen je društvenim mrežama i e-poštom. U istraživanje su uključeni ispitanici koji imaju 18 i više godina. Ispitanici su se odazvali dobrovoljno te im je bilo potrebno prosječno 30-40 minuta za ispunjavanje 
upitnika i odgovaranje na moralne dileme. U uputi je objašnjena svrha istraživanja i način ispunjavanja te je naglašena anonimnost, povjerljivost i grupna analiza podataka. Navedena je mogućnost odustajanja u bilo kojem trenutku, e-adresa autora istraživanja za kontakt i na kraju je ispitanicima zahvaljeno na sudjelovanju. Dobiven je informirani pristanak označavanjem polja 'slažem se' na pitanje dobrovoljnog sudjelovanja u istraživanju. Ispitanici su prvo odgovorili na demografska pitanja, zatim su ispunjavali Skalu emocionalne empatije, Skalu socijalne poželjnosti, Upitnik narcističke ličnosti, Test makijavelizma, Skalu samoprocjene psihopatije, a na kraju istraživanja odgovarali su na moralne dileme.

\section{Rezultati}

Distribucija dobi ispitanika izrazito je odstupala od normalne (indeks asimetričnosti $=1.96$; indeks spljoštenosti $=3.57$, pa je zbog toga izvršena logaritamska transformacija, koja je rezultirala smanjenjem indeksa asimetričnosti na 1.35 , a indeksa spljoštenosti na 1.31. Korelacija između izvorne i transformirane dobi iznosi $r=.99(p<.01)$. Deskriptivni podaci ostalih varijabli korištenih $\mathrm{u}$ istraživanju prikazani su u Tablici 1.

Tablica 1.

Deskriptivna statistika za kontinuirane varijable $(N=210)$

\begin{tabular}{lrrrrrc}
\hline varijabla & \multicolumn{1}{c}{$M$} & \multicolumn{1}{c}{$S D$} & raspon & IA & IS & Cronbach $\alpha$ \\
\hline emocionalna empatija & 55.40 & 10.23 & $13-76$ & -.58 & 1.06 & .89 \\
socijalna poželjnost & 6.24 & 2.67 & $0-13$ & -.02 & -.54 & .64 \\
narcizam & 11.56 & 6.03 & $0-33$ & .77 & .54 & .82 \\
makijavelizam & 62.33 & 10.75 & $39-94$ & .37 & -.17 & .70 \\
psihopatija & 62.48 & 12.13 & $38-96$ & .58 & .18 & .82 \\
moralna prosudba & 2.42 & 0.83 & $1-4$ & .02 & -.74 & .87 \\
\hline
\end{tabular}

$\mathrm{IA}=$ indeks asimetričnosti, IS = indeks spljoštenosti

Kako bi se ispitala povezanost svih varijabli korištenih u istraživanju izračunati su Pearsonovi koeficijenti korelacije (Tablica 2.). 
Tablica 2.

Pearsonovi koeficijenti korelacija između demografskih varijabli, rezultata na upitnicima, moralnim dilemama i moralne prosudbe $(N=210)$

\begin{tabular}{lcccccccc}
\hline & $\begin{array}{c}\text { dob } \\
(\log )\end{array}$ & 1 & 2 & 3 & 4 & 5 & 6 & 7 \\
\hline 1 spol & -.10 & & & & & & & \\
2 obrazovanje & $.46^{* *}$ & -.03 & & & & & & \\
3 emoc. empatija & .11 & $.25^{* *}$ & .01 & & & & & \\
4 narcizam & -.10 & -.07 & .01 & $-.15^{*}$ & & & & \\
5 makijavelizam & -.12 & -.07 & -.05 & $-.23^{* *}$ & $.25^{* *}$ & & & \\
6 psihopatija & $-.16^{*}$ & $-.26^{* *}$ & $-.14^{*}$ & $-.20^{* *}$ & $.38^{* *}$ & $.30^{* *}$ & & \\
7 soc. poželjnost & .11 & .08 & .04 & .09 & -.13 & $-.32^{* *}$ & $-.29^{* *}$ & \\
8 MP & -.03 & $-.19^{* *}$ & .11 & $-.40^{* *}$ & .10 & $.24^{* *}$ & $.27^{* *}$ & $-.18^{*}$ \\
\hline
\end{tabular}

spol $(0=$ muškarci, $1=$ žene $) ; \mathrm{MP}=$ moralna prosudba

${ }^{*} p \leq .05{ }^{* *} p \leq .01$.

Iz Tablice 2. vidljivo je da muškarci postižu niže rezultate na emocionalnoj empatiji, a više na psihopatiji i utilitarističkoj moralnoj prosudbi. Dob i stupanj obrazovanja značajno koreliraju samo s psihopatijom, i to negativno. Socijalna je poželjnost povezana s deontološkom moralnom prosudbom i nižim makijavelizmom te psihopatijom. Emocionalna je empatija povezana s deontološkom moralnom prosudbom i s nižim rezultatima na sve tri crte ličnosti tamne trijade, koje su međusobno u značajnim pozitivnim korelacijama. Narcizam ne korelira s moralnom prosudbom, dok su makijavelizam i psihopatija povezani s utilitarističkom moralnom prosudbom.

Hijerarhijska regresijska analiza provedena je kako bi se ustanovio doprinos crta ličnosti tamne trijade na moralnu prosudbu nakon kontrole spola, dobi, socijalne poželjnosti i emocionalne empatije koja je pokazala najveću korelaciju $(r=-.40 ; p<$ .01) s kriterijem. U prvom koraku uvršteni su spol, dob i socijalna poželjnost, u drugom emocionalna empatija, a u trećem crte ličnosti tamne trijade. Provjera faktora inflacije varijance i koeficijenata tolerancije pokazala je da ne postoji značajna multikolinearnost među prediktorima. Rezultati hijerarhijske regresijske analize, standardizirani $(\beta)$ regresijski koeficijenti pojedinih prediktora i njihove značajnosti prikazane su u Tablici 3. 
Tablica 3.

Rezultati hijerarhijske regresijske analize sa spolom, socijalnom poželjnošću, emocionalnom empatijom i crtama tamne trijade kao prediktorima moralne prosudbe

\begin{tabular}{lccc}
\hline prediktori & \multicolumn{3}{c}{ kriterij: moralna prosudba } \\
\hline 1. korak & $\beta$ & $r$ & $s r$ \\
\hline spol & $-.18^{* *}$ & $-.19^{* *}$ & $-.17^{*}$ \\
dob (log) & -.03 & -.03 & -.03 \\
socijalna poželjnost & $-.16^{*}$ & $-.18^{*}$ & $-.16^{*}$ \\
\hline$R=.25 ; R^{2}=.06^{* *} ; \Delta R^{2}=.06^{* *}$ & & & \\
\hline 2. korak & $\beta$ & $r$ & $s r$ \\
\hline Spol & -.08 & $-.19^{* *}$ & -.08 \\
Dob (log) & .02 & -.03 & .02 \\
Socijalna poželjnost & $-.14^{*}$ & $-.18^{*}$ & $-.14^{*}$ \\
Emocionalna empatija & $-.37^{* *}$ & $-.40^{* *}$ & $-.36^{* *}$ \\
\hline$R=.43 ; R^{2}=.19^{* *} ; \Delta R^{2}=.13^{* *}$ & & & $s r$ \\
\hline 3. korak & $\beta$ & $r$ & -.04 \\
\hline spol & -.05 & $-.19^{* *}$ & .04 \\
dob (log) & .05 & -.03 & -.07 \\
socijalna poželjnost & -.07 & $-.18^{*}$ & $-.32^{* *}$ \\
emocionalna empatija & $-.34^{* *}$ & $-.40^{* *}$ & -.04 \\
narcizam & -.04 & .10 & .09 \\
makijavelizam & .10 & $.24^{* *}$ & $.13^{*}$ \\
psihopatija & $.16^{*}$ & $.27^{* *}$ & \\
\hline$R=.47 ; R^{2 *}$ & & & \\
\hline
\end{tabular}

$R=.47 ; R^{2}=.22^{* *} ; \Delta R^{2}=.03^{*}$

spol $(0=$ muškarci, 1 = žene); $r=$ Pearsonov koeficijent korelacije; $s r=$ semiparcijalna korelacija; $\beta=$ standardizirani regresijski $B$ koeficijent; $R=$ koeficijent multiple korelacije; $R^{2}=$ proporcija ukupno objašnjene varijance; $\Delta R^{2}=$ promjena u proporciji objašnjene varijance

${ }^{*} p \leq .05 ;{ }^{* *} p \leq .01$.

Rezultati pokazuju da je regresijskim modelom ukupno objašnjeno $22 \%$ varijance moralne prosudbe. Spol, dob i socijalna poželjnost sami objašnjavaju $6 \%$ varijance, a emocionalna empatija dodatnih $13 \%$ varijance. Crte tamne trijade u trećem koraku dodatno objašnjavaju 3\% varijance moralne prosudbe. U prvom su koraku spol i socijalna poželjnost značajni negativni prediktori utilitarističke moralne prosudbe, međutim, kada se u drugom koraku uvrsti emocionalna empatija, spol gubi na značajnosti. Socijalna poželjnost je značajan negativan prediktor još u drugom, ali ne i u trećem koraku, kada se u analizu uključe crte tamne trijade. Emocionalna empatija je i u drugom i u trećem koraku značajan negativan prediktor utilitarističke moralne prosudbe. Od crta tamne trijade jedino je psihopatija bila značajan pozitivan prediktor utilitarističke moralne prosudbe. Dakle, u konačnom modelu niža emocionalna empatija i viša psihopatija značajni su prediktori utilitarističke moralne prosudbe. 
Kako bi se provjerio medijacijski efekt emocionalne empatije na povezanost crta ličnosti tamne trijade i sklonosti deontološkom odnosno utilitarističkom odgovoru na moralne dileme, proveden je niz regresijskih analiza te je korištena metoda Barona i Kennyja (1986), prema kojoj treba zadovoljiti sljedeće uvjete kako bi se moglo zaključiti da je neka varijabla medijator u odnosu prediktora i kriterija: prediktor treba imati značajan efekt na kriterij, prediktor treba imati značajan efekt na medijator i medijator treba imati značajan efekt na kriterij. Kad doprinos prediktora u objašnjenju varijance kriterija uz kontrolu efekta medijatora prestaje biti značajan, tada je riječ o potpunoj medijaciji, a ako je taj doprinos smanjen, ali i dalje značajan, radi se o djelomičnoj medijaciji. Budući da narcizam nije pokazao statistički značajnu povezanost s moralnom prosudbom, ispitan je medijacijski efekt samo za makijavelizam i psihopatiju.

Najprije je ispitana uloga emocionalne empatije na odnos makijavelizma i sklonosti utilitarističkog odgovora na moralne dileme. Rezultati analize medijacije prikazani su na Slici 1.

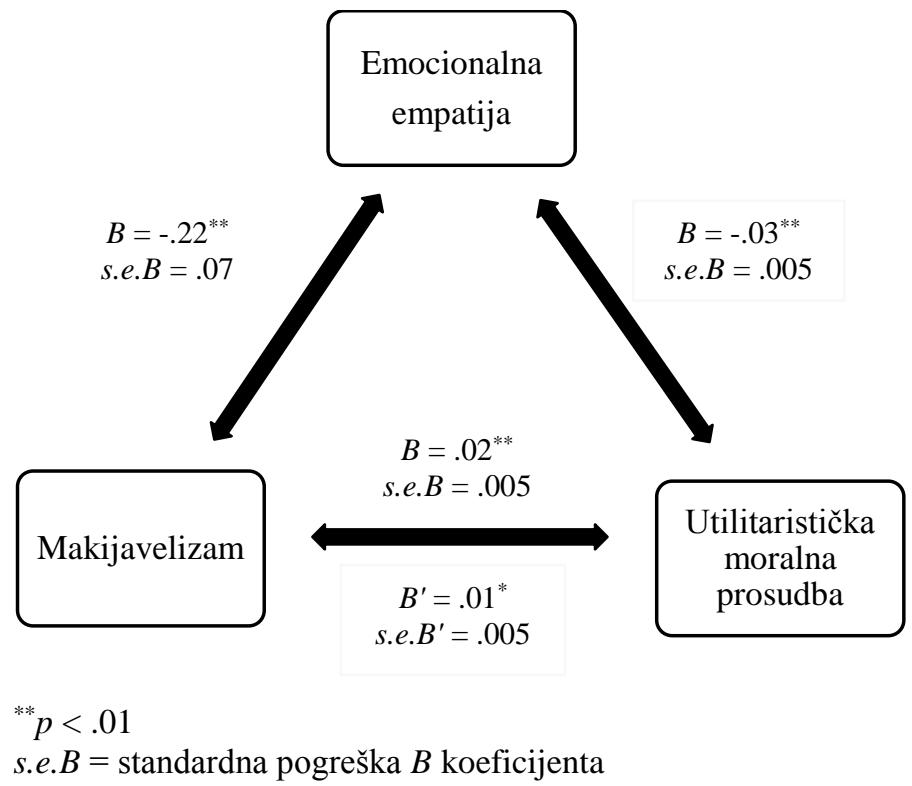

Slika 1. Medijacijski efekt emocionalne empatije na odnos makijavelizma i utilitarističke moralne prosudbe.

Rezultati pokazuju da makijavelizam ima statistički značajan efekt na utilitarističku moralnu prosudbu $(B=.02 ; p<.01)$ i na emocionalnu empatiju $(B=-$ $.22 ; p<.01)$ te da emocionalna empatija ima statistički značajan efekt na utilitarističku moralnu prosudbu $(B=-.03 ; p<.01)$. Kada se kontrolira efekt emocionalne empatije na utilitarističku moralnu prosudbu, efekt makijavelizma 
idalje je značajan, ali smanjen $\left(B^{\prime}=.01 ; p>.05\right)$, što upućuje na djelomičnu medijaciju: efekt makijavelizma na sklonost utilitarističkom odgovoru na moralne dileme dijelom je posredovan emocionalnom empatijom.

Nakon toga je na odnos psihopatije i utilitarističke moralne prosudbe ispitana uloga emocionalne empatije. Rezultati analize medijacije prikazani su na Slici 2.

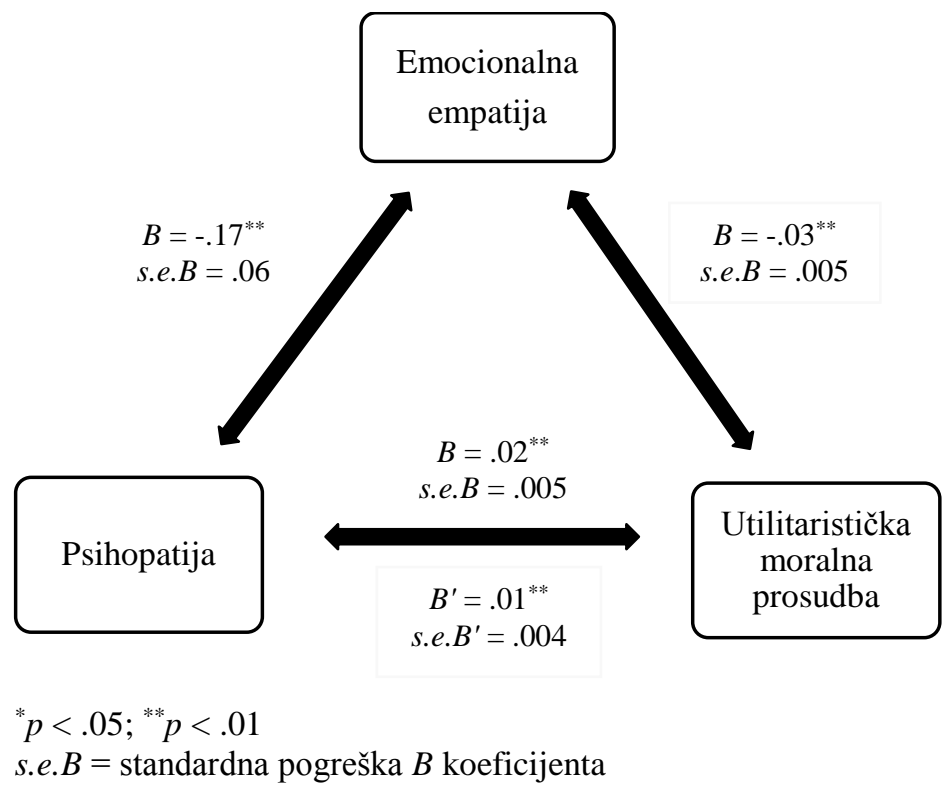

Slika 2. Medijacijski efekt emocionalne empatije na odnos psihopatije i utilitarističke moralne prosudbe.

Rezultati pokazuju da psihopatija ima statistički značajan efekt na utilitarističku moralnu prosudbu $(B=.02 ; p<.01)$ i na emocionalnu empatiju $(B=-.17 ; p<.01)$, te da emocionalna empatija ima statistički značajan efekt na utilitarističku moralnu prosudbu $(B=-.03 ; p<.01)$. Kada se kontrolira efekt emocionalne empatije na utilitarističku moralnu prosudbu, efekt psihopatije idalje je značajan, ali smanjen ( $B^{\prime}$ $=.01 ; p<.05)$, što upućuje na djelomičnu medijaciju: efekt psihopatije na sklonost utilitarističkom odgovoru na moralne dileme djelomično je posredovan emocionalnom empatijom.

\section{Rasprava}

Slično su kao i u prijašnjim istraživanjima (Furnham i sur., 2014) dobivene niske do umjerene pozitivne korelacije između crta ličnosti tamne trijade. Dob i stupanj obrazovanja pokazuju nisku negativnu povezanost sa psihopatijom, što znači da mlađi ispitanici i oni nižeg obrazovanja (vjerojatno zbog svoje mladosti) postižu 
više rezultate na skali psihopatije. Ispitanici skloniji socijalno poželjnom odgovaranju, odnosno izbjegavanju neodobravanja, imaju niže rezultate na skalama makijavelizma i psihopatije te manju preferenciju za utilitarističke moralne prosudbe. Takve povezanosti nisu neočekivane s obzirom na nalaze Uhlmanna, Zhua i Tannenbauma (2013), čiji su ispitanici davali negativne atribucije o moralnosti karaktera ljudi koji daju utilitarističke moralne prosudbe, iako su smatrali da su prosudbe koje donose ispravne ili pragmatične. To se objašnjava time da ne možemo znati motivaciju osobe koja je donijela prosudbu, pa možemo pretpostaviti i manje plemenite razloge poput smanjene empatije za žrtvu u moralnoj dilemi ili želje da se žrtvi naudi. Prema tome, osobe koje teže socijalnoj poželjnosti i izbjegavaju neodobravanje ne žele biti povezane s osobinama i prosudbama koje bi drugi percipirali kao nepoželjne ili negativne. Emocionalna empatija pokazuje niske do umjerene korelacije s većinom istraživanih varijabli. S crtama tamne trijade je nisko negativno povezana, dok je s prosječnom utilitarističkom moralnom prosudbom u umjereno visokoj značajnoj negativnoj korelaciji, a što je sve u skladu s nalazima prijašnjih istraživanja (Gleichgerrcht i Young, 2013; Jones i Figueredo, 2013; Patil i Silani, 2014; Wai i Tiliopoulos, 2012).

Rezultati ovoga istraživanja pokazuju da su makijavelizam i psihopatija povezani $\mathrm{s}$ utilitarističkom moralnom prosudbom, dok narcizam nije značajno povezan s moralnom prosudbom. Bartels i Pizzaro (2011) također su dobili statistički značajne pozitivne povezanosti makijavelizma i psihopatije $s$ utilitarističkom moralnom prosudbom, dok su Djeriouat i Tremoliere (2014) za sve tri crte tamne trijade ustanovili statistički značajne pozitivne povezanosti s utilitarističkom moralnom prosudbom, ali ipak najmanju za narcizam. Ovakvi su rezultati u skladu s istraživanjem Jonasona i sur. (2015a) prema kojem je psihopatija povezana sa smanjenom brigom za sve moralne temelje, a narcizam sa socijalno poželjnim oblikom moralnosti. Pojedinci s izraženim narcizmom pokazuju socijalno poželjnu moralnost, a utilitaristička moralna prosudba dovodi do negativne atribucije o moralnosti karaktera osobe koja ju donosi, što se kosi s narcističkim potrebama za potvrdom i divljenjem i može predstavljati prijetnju selfu (Uhlmann i sur., 2013).

Što se tiče spola, on pokazuje niske do umjerene korelacije s nekoliko istraživanih varijabli. Žene iskazuju višu emocionalnu empatiju i nižu psihopatiju te su više sklone deontološkoj prosudbi. Takav je obrazac očekivan jer i prethodna istraživanjima nalaze nižu psihopatiju (npr. Ali, Amorim i Chamorro-Premuzic, 2009), višu empatiju (npr. Jonason i Kroll, 2015; Wai i Tiliopoulos, 2012) i manju sklonost utilitarističkoj prosudbi (npr. Bartels i Pizzaro, 2011) kod žena u odnosu na muškarce. Evolucijska perspektiva nudi objašnjenje za ovakve rezultate. Budući da je jedan od najkonzistentnijih nalaza da muškarci postižu više rezultate na skalama tamne trijade, Jonason, Li, Webster i Schmitt (2009) smatraju da spolne razlike u tim crtama pomažu objasniti činjenicu da su muškarci skloniji koristiti kratkoročnu reproduktivnu strategiju u odnosu na žene. Kasnija su istraživanja pokazala da samo psihopati koriste jasnu impulzivnu reproduktivnu strategiju (Jones i Paulhus, 2011). 
Dok psihopati povećavaju svoje reproduktivne mogućnosti impulzivnom i agresivnom reproduktivnom strategijom, makijavelisti imaju koristi od više strateškog i reguliranog reproduktivnog stila koji održava vezu. Manja je sklonost utilitarističkoj moralnoj prosudbi kod žena pronađena i u drugim istraživanjima, poput istraživanja Fumagalli i sur. (2010), u okviru kojeg je pronađena razlika u osobnim moralnim dilemama na koje žene daju statistički značajno manje utilitarističkih moralnih prosudbi od muškaraca, dok u neosobnim i ne-moralnim dilemama nije bilo razlike. Fumagalli i sur. (2010) sugeriraju da se kognitivnoemocionalni procesi uključeni u evaluaciju osobnih dilema razlikuju kod muškaraca i žena te moguće odražavaju razlike u neuralnim mehanizmima. Nalazi su vjerojatno povezani sa spolnim razlikama u empatiji. Moralno je prosuđivanje kod žena usmjereno na izbjegavanje povrede drugih ljudi, jer daju veliku važnost socijalnim odnosima i ispunjavanju tuđih očekivanja. S druge strane, moralno se prosuđivanje kod muškaraca temelji na apstraktnim principima pravde i pravednosti.

Crte ličnosti tamne trijade, spol, socijalna poželjnost i emocionalna empatija zajedno objašnjavaju $22 \%$ varijance moralne prosudbe. Emocionalna je empatija statistički značajan negativan prediktor, dok je od crta ličnosti tamne trijade jedino psihopatija statistički značajan, i to pozitivan prediktor utilitarističke moralne prosudbe. Ovakvi su rezultati očekivani s obzirom na korelacijske obrasce među varijablama, a ujedno su i konzistentni s nalazima Djeriouata i Tremolierea (2014). Medijacijski je efekt emocionalne empatije ispitan samo za makijavelizam i psihopatiju, jer narcizam nije pokazao značajnu povezanost s moralnom prosudbom. U oba je slučaja dobivena djelomična medijacija, odnosno nakon isključivanja efekta niske emocionalne empatije, i makijavelizam i psihopatija idalje značajno predviđaju utilitarističku moralnu prosudbu, ali sa smanjenom prediktivnom snagom. Ti su nalazi također konzistentni rezultatima Djeriouata i Tremolierea (2014), koji su ispitivali medijacijski efekt prosocijalne orijentacije (HEXACO faktor iskrenost/skromnost) i moralne grupe vrijednosti povezanih $\mathrm{s}$ empatijom (šteta/briga) na povezanost crta ličnosti tamne trijade i utilitarističkih moralnih prosudbi vezanih uz žrtvujuće moralne dileme. Šteta/briga i iskrenost/skromnost negativni su medijatori te veze kada su nezavisni prediktori makijavelizam i psihopatija, ali ne i kada je nezavisni prediktor narcizam. Psihopatija je bila jedini nezavisni prediktor štete/brige i utilitarističke moralne prosudbe, pokazujući da niska briga za princip štete i prosocijalna ponašanja, odnosno inhibicija moralne deontologije, može dovesti do utilitarističke moralne prosudbe. Choe i Min (2011) te Gleichgerrcht i Young (2013) su također pokazali da je niska empatična briga povezana s utilitarističkom moralnom prosudbom, dok su Patil i Silani (2014) uočili pozitivnu povezanost aleksitimije, koja pokazuje deficite u empatiji, s utilitarističkom moralnom prosudbom.

Dobiveni rezultati potenciraju značaj razmatranja Bartelsa i Pizzara (2011), koji se fokusiraju na metodološka pitanja o kriteriju za određivanje optimalne moralnosti u dilemama žrtvovanja. Oni smatraju da odabir utilitarističke opcije nije uvijek 
posljedica motivacije za postizanjem većeg dobra, nego može biti posljedica smanjene emocionalne osjetljivosti. Kahane (2015) također smatra da nije plauzibilno da osobe s izraženim antisocijalnim osobinama ili niskim razinama empatije promiču dobrobit ili brinu za čovječanstvo u cjelini, ali ujedno navodi i da amoralna, egoistična perspektiva i nepristrana utilitaristička briga za veće dobro, dijele važne strukturalne značajke: obje se koriste analizom troškova i dobitaka za usmjeravanje akcije, i obje imaju tendenciju zanemarivanja zdravorazumskih moralnih normi. Ono što razlikuje utilitariste od egoista, to je što se prvi brinu za veće dobro, a drugi samo za svoje (Kahane, 2015). Međutim, rezultati istraživanja koje su proveli Kahane, Everett, Earp, Farias i Savulescu (2015) sugeriraju da postoji mala povezanost između utilitarističkih prosudbi u moralnim dilemama žrtvovanja koje dominiraju u području psihologije morala s pravim utilitarističkim pristupom u etici. Oni su ustanovili da je utilitaristička moralna prosudba na dilemama žrtvovanja povezana sa širim nemoralnim pogledom, s jasnim etičkim prijestupima u poslovnom kontekstu, subkliničkom psihopatijom, većim odobravanjem racionalnog egoizma, manjom donacijom novca u dobrotvorne svrhe te manjom identifikacijom s cijelim čovječanstvom, što je središnja značajka klasičnog utilitarizma.

Neovisno o tome predstavljaju li utilitarističke moralne prosudbe u moralnim dilemama žrtvovanja stvarno zagovaranje utilitarizma kao etičke pozicije, moralne dileme žrtvovanja ne uspijevaju razlikovati ljude koji su motivirani donositi utilitarističke moralne izbore zbog pozadinskih emocionalnih deficita i onih koji ih čine zbog iskrene brige za tuđu dobrobit te bi se trebalo raditi na tome da se uvedu nove eksperimentalne metode proučavanja moralnog prosuđivanja ili poboljšaju trenutne. Conway i Gawronski (2013) smatraju da problem leži u tradicionalnom korištenju jednoga bipolarnog indeksa deontoloških i utilitarističkih prosudbi te zagovaraju korištenje dva odvojena indeksa. Kategorizacijom neke štetne akcije kao prihvatljive ili neprihvatljive pojedinci odobravaju ili deontološki ili utilitaristički princip te se miješa odabir jedne opcije $s$ odbacivanjem druge. Ovakav bi pristup bio dobar kad bi deontološke i utilitarističke prosudbe bile obrnuto povezane. No teoretičari smatraju da su te prosudbe distinktivne i funkcioniraju nezavisno, pa je, stoga, moguće da su prisutne istovremeno. Istraživanje se moralnih dilema temelji na pretpostavci da dileme izazivaju konflikt između dviju sklonosti i da ona jača vodi bihevioralni odgovor (prosudbu je li neka akcija moralno prihvatljiva ili ne). Studija Conwaya i Gawronskog (2013) pokazala je da kognitivno opterećenje (ispitanici su morali pamtiti šifru prije svake dileme) selektivno smanjuje utilitarističke sklonosti, dok su deontološke ostale izvan tog utjecaja. U drugoj su studiji manipulacijom kojom je povećana empatija (prikazana je slika osobe koja bi bila ozlijeđena u dilemi) povećane deontološke, ali ne i utilitarističke sklonosti. Conway i Gawronski (2013) su koristili Jacobyjevu proceduru disocijacije procesa kako bi nezavisno kvantificirali snagu deontoloških i utilitarističkih prosudbi kod pojedinaca. Umjesto tradicionalnoga jednoga bipolarnog indeksa dobivena su dva nezavisna indeksa. Središnja je ideja u podlozi ove procedure usporedba odgovora na inkongruentnim 
dilemama, u kojima deontologija i utilitarizam dovode do različitih odgovora $\mathrm{i}$ kongruentnih, u kojima procesi dovode do istog odgovora.

Kahane (2015) ipak vidi i nešto dobro u moralnim dilemama, odnosno ne slaže se s prigovorom da je njihova nerealističnost negativna. On smatra da takvi scenariji omogućuju da bolje izoliramo distinktne moralne varijable te omogućuju istraživanje prosudbi koje nisu samo odraz socijalnih konvencija. Christensen i Gomila (2012) također smatraju da nam moralne prosudbe na hipotetske moralne dileme daju vrijedne informacije o psihološkim procesima u podlozi ljudske moralne kognicije. "Udaljene" situacije koje uključuju ozbiljne moralne transgresije posebno su vrijedne time što nam dopuštaju kontroliranje različitih neželjenih efekta izlaganja ili razine prijašnje izloženosti ekstremnim situacijama i istraživanje kakav efekt to ima na moralno prosuđivanje. Stoga dileme potiču, a ne smanjuju ekološku valjanost.

Najveće je ograničenje ovog rada to što je korelacijskog tipa, pa ne omogućuje donošenje kauzalnih zaključaka. Određeni nedostaci proizlaze i iz metode internetskog upitnika: Google docs, naime, ne omogućuje rotaciju redoslijeda upitnika ni odgovarajući slučajan redoslijed čestica, stoga nije kontroliran efekt umora, motivacije i utjecaja redoslijeda upitnika na odgovaranje. Osim toga, korištenjem internetskog upitnika nije moguće rigorozno kontrolirati odgovore ispitanika na demografska pitanja, kao ni kontrolirati tko je sve pristupio ispitivanju, odnosno koji je postotak odbijanja ispitanika te kakve su njihove karakteristike. Ipak, ovakva metoda ima i određenih prednosti. Osim ekonomičnosti i jednostavnosti internetski upitnici omogućuju doživljaj veće anonimnosti ispitanicima, kojima bi sama prisutnost istraživača moguće izazvala nelagodu i/ili veće socijalno poželjno odgovaranje (Fiškuš i Švegar, 2018). Dobiveni uzorak ispitanika pokazuje određene pristranosti koje umanjuju generalizabilnost rezultata. Ispitanici su većinom mlađe dobi (20-30 godina), ženskog spola i višeg stupnja obrazovanja. Zbog velike razlike u broju muških i ženskih ispitanika nije bilo moguće raditi analize odvojeno za svaki spol. Osim toga, u istraživanju su većinom korištene mjere samoprocjene crta ličnosti, koje imaju određene nedostatke, poput nemogućnosti provjere istinitosti odgovora, nerazumijevanja pitanja i sl. Od mjera koje su korištene sve imaju zadovoljavajuću pouzdanost osim mjere socijalne poželjnosti kod koje je pouzdanost nešto niža od prikladne, no to može biti i rezultat malog broja čestica. Neki su se ispitanici žalili na dugotrajnost ispunjavanja upitnika, a s obzirom na to da $\mathrm{u}$ internetskim istraživanjima duljina upitnika može predstavljati objektivan problem (Maliković, Švegar i Šomođi, 2017), ubuduće bi bilo poželjno koristiti kraće mjere crta tamne trijade poput Dirty Dozen (Jonason i Webster, 2010) ili Short Dark Triad (Jones i Paulhus, 2014).

Buduća bi se istraživanja trebala usmjeriti na rasvjetljavanje motivacije u pozadini deontološke odnosno utilitarističke moralne prosudbe na moralne dileme žrtvovanja. Uz moralne dileme mogao bi se koristiti i niz pitanja koja se odnose na različite situacije i opće stavove vezane uz odobravanje utilitarizma ili deontologije, što bi pomoglo u interpretaciji rezultata. Također bi se mogle koristiti 
eksperimentalne metode induciranja određenih emocija i ispitivanja utjecaja emocija na moralno prosuđivanje u moralnim dilemama. Postoji potreba i za konstrukcijom novog skupa moralnih dilema i drugih mjera koje ispituju moralno prosuđivanje, čemu bi trebalo pristupiti interdisciplinarno, kako bi mjere metodološki i konceptualno bile adekvatne.

\section{Literatura}

Ali, F., Amorim, I. S. i Chamorro-Premuzic, T. (2009). Empathy deficits and trait emotional intelligence in psychopathy and Machiavellianism. Personality and Individual Differences, 47, 758-762.

Barlow, A., Qualter, P. i Stylianou, M. (2010). Relationship between Machiavellianism, emotional intelligence and theory of mind in children. Personality and Individual Differences, 48, 78-82.

Baron, R. M. i Kenny, D. A. (1986). The moderator-mediator variable distinction in social psychological research: Conceptual, strategic, and statistical considerations. Journal of Personality and Social Psychology, 51, 1173-1182.

Bartels, D. M. i Pizarro, D. A. (2011). The mismeasure of morals: Antisocial personality traits predict utilitarian responses to moral dilemmas. Cognition, 121, 154-161.

Bezinović, P. (1988). Percepcija osobne kompetentnosti kao dimenzija samopoimanja. (Neobjavljena doktorska disertacija). Filozofski fakultet, Sveučiište u Zagrebu, Zagreb.

Campbell, W. K., Reeder, G. D., Sedikides, C. i Elliot, A. T. (2000). Narcissism, and comparative self-enhancement strategies. Journal of Research in Personality, 34, 329347.

Choe, S. Y. i Min, K. H. (2011). Who makes utilitarian judgments? The influences of emotions on utilitarian judgments. Judgment and Decision Making, 6, 580-592.

Christensen, J. F. i Gomila, A. (2012). Moral dilemmas in cognitive neuroscience of moral decision-making: A principled review. Neuroscience \& Biobihevioral Reviews, 36, 1249-1264.

Christie, R. i Geis, F. L. (1970). Studies in Machiavellianism. New York: Academic Press.

Conway, P. i Gawronski, B. (2013). Deontological and utilitarian inclinations in moral decision making: A process dissociation approach. Journal of Personality and Social Psychology, 104, 216-235.

Crowne, D. P. i Marlowe, D. (1964). The approval motive. New York: Wiley.

Delič, L., Novak, P., Kovačič, J. i Avsec, A. (2011). Self- reported emotional and social intelligence and empathy as distinctive predictors of narcissism. Psychological Topics, 20, 477-488. 
Djeriouat, H. i Trémolière, B. (2014). The Dark Triad of personality and utilitarian moral judgment: The mediating role of Honesty/Humility and Harm/Care. Personality and Individual Differences, 67, 11-16.

Fehr, B., Samsom, D. i Paulhus, D. L. (1992). The construct of machiavellianism: Twenty years later. U: C. D. Spielberger i J. N. Butcher (Ur.), Advances in personality assessment (str. 77-116). New York: Routledge.

Fiškuš, M. i Švegar, D. (2018). Socijalno poželjno odgovaranje i vrijeme latencije u kontekstu selekcijskoga postupka pri zapošljavanju. Zbornik Veleučilišta u Rijeci, 6, 1-12.

Fumagalli, M., Ferrucci, R., Mameli, F., Marceglia, S., Mrakic-Sposta, S., Zago, S., ... Priori, A. (2010). Gender-related differences in moral jugdment. Cognitive Processing, 11, 219-226.

Furnham, A., Richards, S., Rangel, L. i Jones, D. N. (2014). Measuring malevolence: Quantitative issues surrounding the Dark Triad of personality. Personality and Individual Differences, 67, 114-121.

Gleichgerrcht, E. i Young, L. (2013). Low levels of empathic concern predict utilitarian moral judgment. PLOS ONE, 8, 1-9.

Glenn, A. L., Iyer, R., Graham, J., Koleva, S. i Haidt, J. (2009). Are all types of morality compromised in psychopathy? Journal of Personality Disorders, 23, 384-398.

Greene, J. D., Cushman, F. A., Stewart, L. E., Lowenberg, K., Nystrom, L. E. i Cohen, J. D. (2009). Pushing moral buttons: The interaction between personal force and intention in moral judgment. Cognition, 111, 364-371.

Greene, J., Morelli, S., Lowenberg, K., Nystrom, L. i Cohen, J. (2008). Cognitive load selectively interferes with utilitarian moral judgment. Cognition, 107, 1144-1154.

Greene, J. D., Nystrom, L. E., Engell, A. D., Darley, J. M. i Cohen, J. D. (2004). The neural bases of cognitive conflict and control in moral judgment. Neuron, 44, 389-400.

Greene, J. D., Sommerville, R. B., Nystrom, L. E., Darley, J. M. i Cohen, J. D. (2001). An fMRI investigation of emotional engagement in moral judgment. Science, 293, 21052108.

Haidt, J. (2001). The emotional dog and its rational tail: A social intuitionist approach to moral judgment. Psychological Review, 108, 814-834.

Haidt, J. i Graham, J. (2007). When morality opposes justice: Conservatives have moral intuitions that liberals may not recognize. Social Justice Research, 20, 98-116.

Hare, R. D. (1985). Comparison of procedures for the assessment of psychopathy. Journal of Consulting and Clinical Psychology, 53, 7-16.

Hare, R. D. (1991). The Hare Psychopathy Checklist - Revised. North Tonawanda, NY: Multi-Health Systems.

Jonason, P. K., Duineveld, J. J. i Middleton, J. P. (2015). Pathology, pseudopathology, and the Dark Triad of personality. Personality and Individual Differences, 78, 43-47. 
Jonason, P. K. i Krause, L. (2013). The emotional deficits associated with the Dark Triad traits: Cognitive empathy, affective empathy, and alexithymia. Personality and Individual Differences, 55, 532-537.

Jonason, P. K. i Kroll, C. H. (2015). A multidimensional view of the relationship between empathy and the Dark Triad. Journal of Individual Differences, 36, 150-156.

Jonason, P. K., Li, N. P., Webster, G. D. i Schmitt, D. P. (2009). The Dark Triad: Facilitating a short-term mating strategy in men. European Journal of Personality, 23, 5-18.

Jonason, P. K., Lyons, M., Bethell, E. i Ross, R. (2013). Different routes to limited empathy in the sexes: Examining the links between the Dark Triad and empathy. Personality and Individual Differences, 57, 572-576.

Jonason, P. K., Strosser, G. L., Kroll, C. H., Duineveld, J. J. i Baruffi, S. A. (2015a). Valuing myself over others: The Dark Triad traits and moral and social values. Personality and Individual Differences, 81, 102-106.

Jonason, P. K. i Webster, G. D. (2010). The Dirty Dozen: A concise measure of the Dark Triad. Psychological Assessment, 22, 420-432.

Jones, D. N. i Figueredo, A. J. (2013). The core of darkness: Uncovering the heart of the Dark Triad. European Journal of Personality, 27, 521-531.

Jones, D. N. i Paulhus, D. L. (2011). The role of impulsivity in the Dark Triad of personality. Personality and Individual Differences, 51, 670-682.

Jones, D. N. i Paulhus, D. L. (2014). Introducing the Short Dark Triad (SD3): A short measure of dark personality traits. Assessment, 21, 28-41.

Kahane, G. (2015). Sidetracked by trolleys: Why sacrificial moral dilemmas tell us little (or nothing) about utilitarian judgment. Social Neuroscience, 10, 551-560.

Kahane, G., Everett, J. A. C., Earp, B. D., Farias, M. i Savulescu, J. (2015). Utilitarian judgments in sacrificial moral dilemmas do not reflect impartial concern for the greater good. Cognition, 134, 193-209.

Kardum, I., Hudek-Knežević, J., Schmitt, D. P. i Grundler, P. (2015). Personality and mate poaching experiences. Personality and Individual Differences, 75, 7-12.

Kohlberg. L. (1969). Stage and sequence: The cognitive-developmental approach to socialization. U: D. A. Goslin (Ur.), Handbook of socialisation theory and research (str. 347-480). Chicago: Rand McNally.

Mahmut, M. K., Homewood, J. i Stevenson, R. J. (2008). The characteristics of noncriminals with high psychopathy traits: Are they similar to criminal psychopaths? Journal of Research in Personality, 42, 679-692.

Maliković, M., Švegar, D. i Šomođi, S. (2017). Utjecaj vizualne orijentacije skale za odgovaranje i broja stranica web-upitnika na rezultate ispitivanja. Zbornik Veleučilišta u Rijeci, 5, 1-12.

Moll, J. i de Oliveira-Souza, R. (2007). Moral judgments, emotions and the utilitarian brain. Trends in Cognitive Sciences, 11, 319-321. 
Moore, A. B., Clark, B. A. i Kane, M. J. (2008). Who shalt not kill? Individual differences in working memory capacity, executive control, and moral judgment. Psychological Science, 19, 549-557.

Patil, I. i Silani, G. (2014). Reduced empathic concern leads to utilitarian moral judgments in trait alexithymia. Frontiers in Psychology, 5, 1-12.

Paulhus, D. L. i Williams, K. M. (2002). The Dark Triad of personality: Narcissism, Machiavellianism and psychopathy. Journal of Research in Personality, 36, 556-563.

Paxton, J. M., Ungar, L. i Greene, J. D. (2011). Reflection and reasoning in moral judgment. Cognitive Science, 35, 1-15.

Raboteg-Šarić, Z. (2002). E-upitnik: Skala emocionalne empatije i skala mašte. U: K. Lacković-Grgin, A. Proroković, V. Ćubela i Z. Penezić (Ur.), Zbirka psihologijskih skala i upitnika, Svezak 1 (str. 44-49). Zadar: Filozofski fakultet u Zadru.

Raskin, R. i Hall, C. S. (1979). A Narcissistic Personality Inventory. Psychological Reports, 45, 590.

Raskin, R. i Terry, H. (1988). A principal-components analysis of the Narcissistic Personality Inventory and further evidence of its construct validity. Journal of Personality and Social Psychology, 54, 890-902.

Tangney, J. P., Stuewig, J. i Mashek, D. J. (2007). Moral emotions and moral behavior. Annual Review of Psychology, 58, 345-372.

Uhlmann, E. L., Zhu, L. i Tannenbaum, D. (2013). When it takes a bad person to do the right thing. Cognition, 126, 326-334.

Wai, M. i Tiliopoulos, N. (2012). The affective and cognitive empathic nature of the dark triad of personality. Personality and Individual Differences, 52, 794-799.

Wastell, C. i Booth, A. (2003). Machiavellianism: An alexithymic perspective. Journal of Social and Clinical Psychology, 22, 730-744.

Watson, P. J. i Morris, R. J. (1991). Narcissism, empathy and social desirability. Personality and Individual Differences, 12, 575-579.

Williams, K. M. i Paulhus, D. I. (2004). Factor structure of the self-report psychopathy scale (SRP-II) in non-forensic samples. Personality and Individual Differences, 33, 15201530.

\title{
The Effects of Dark Triad Personality Traits and Emotional Empathy on Moral Judgment
}

\begin{abstract}
Classic sacrificial moral dilemmas, in which it is necessary to sacrifice a life of one person in order to save several other lives, are often defined by the conflict between the rational response of maximizing aggregate welfare (utilitarian moral judgment) and emotional aversion to harm
\end{abstract}


(deontological moral judgment). Recent research in moral judgment shows that socially aversive personality styles are associated with utilitarian response to moral dilemmas. The goal of this study was to examine the relationship between the Dark Triad personality traits and moral judgment, as well as the mediation effect of emotional empathy on that relationship. Two hundred and ten people participated in the study, aged 18-68 years (147 women and 63 men). The results showed that higher psychopathy and higher Machiavellianism are associated with greater endorsement of utilitarian judgment. We found no association between narcissism and moral judgment. Women scored higher on emotional empathy, and men on psychopathy and had higher endorsement of utilitarian judgment. Higher emotional empathy is associated with lower narcissism, lower Machiavellianism and lower psychopathy as well as lower utilitarian judgment. Lower emotional empathy is a significant mediator of the relationship between Machiavellianism and psychopathy and greater endorsement of utilitarian judgment. The effects of the Dark Triad personality traits and emotional empathy on judgment are discussed.

Keywords: Dark Triad personality traits, emotional empathy, moral judgment, sacrificial moral dilemmas

\title{
Efectos de los rasgos de personalidad de tríada oscura y de la empatía emocional sobre juicio moral
}

\begin{abstract}
Resumen
Los dilemas morales clásicos sobre el sacrificio, en los que hay que sacrificar la vida de una persona para salvar varias vidas, a menudo se definen por el conflicto entre la respuesta racional de maximización del bien total (juicio moral utilitario) y la aversión emocional por el daño (juicio moral deontológico). Las investigaciones recientes del juicio moral han demostrado que los estilos de personalidad que son aversivos socialmente también están relacionados con la tendencia hacia la respuesta utilitaria en los dilemas morales. El objetivo de este trabajo fue verificar la relación entre los rasgos de personalidad de tríada oscura y la respuesta en los dilemas morales, tanto como el efecto mediador que tiene la empatía emocional sobre esta relación. En la investigación participaron 210 personas a la edad de entre 18 y 68 años, de los cuales 147 son mujeres y 63 hombres. Los resultados obtenidos demuestran que mayor grado de psicopatía y de maquiavelismo está relacionado con el mayor grado de tendencia hacia el juicio moral utilitario. No se ha comprobado la relación entre el narcisismo y el juicio moral. Las mujeres muestran mayor grado de empatía y los hombres mayor grado de psicopatía, tanto como mayor tendencia hacia el juicio moral utilitario. Mayor empatía emocional se relaciona con menor grado de narcisismo, maquiavelismo y psicopatía, tanto como con menor tendencia hacia el juicio moral utilitario. La empatía emocional baja es un mediador significativo de la relación que el maquiavelismo y la psicopatía tienen con la tendencia hacia el juicio moral utilitario. Se han discutido los efectos que los rasgos de la tríada oscura y de la empatía emocional tienen sobre el juicio moral.
\end{abstract}

Palabras clave: rasgos de personalidad de tríada oscura, empatía emocional, juicio moral, dilemas morales de sacrificio

Primljeno: 20.03.2018. 